LOGI - Scientific Journal on Transport and Logistics

Vol. $12 \quad$ No. $1 \quad 2021 \quad$ DOI: 10.2478/logi-2021-0006

(C) 2021 Z. Gerhátová et al. This is an open access article licensed under the Creative Commons Attribution-NonCommercial-NoDerivs License (http://creativecommons.org/licenses/by-nc-nd/3.0/).

\title{
Analysis of Customs Processing of Wagon Consignment at Slovakia-Ukraine Border
}

\author{
Zuzana Gerhátová $^{1 *}$, Vladislav Zitrický ${ }^{1}$ and Vladimír Klapita ${ }^{1}$
}

${ }^{1}$ Žilinská univerzita $v$ Žiline, Faculty of Operation and Economics of Transport and Communications, Univerzitná 8215/1,010 26 Žilina, Slovakia; Email: zuzana.gerhatova@stud.uniza.sk, vladislav.zitricky@fpedas.uniza.sk,vladimir.klapita@fpedas.uniza.sk

\section{*Corresponding Author: Zuzana Gerhátová}

Received: 13 October 2020; Revised: 19 February 2021; Accepted: 27 April 2021; Published: 26

May 2021

Abstract: In the territory of the Slovak Republic, the transportation of goods from east to west is carried out in Eastern Slovak Trasnsshipment. The transportation of goods in direct international rail transport between the Slovak Republic, the Russian Federation, and Ukraine is carried out through the border crossing points Čierna nad Tisou - Čop and Mat'ovce - Užhorod. These border crossing points are places on a broad-gauge and standard-gauge railway, wherer loading, unloading, and reloading of goods from wider gauge wagons to narrower gauge wagons shall be carried out. There is also a shift of transport mode from SMGS to CIM and other services associated with this transport. An important document affecting the functioning of the single railway market is the Customs Code of the European Union and its provisions. It should be noted that the Common Economic Area of the European Union is also the common customs area of all the Member States. In the case of the crossborder international rail transport organisation, there are no control services due to the customs clearance of the goods. For carriers and customers, this means easier process organisation thanks to the provisions of the Customs Code.

Keywords: International rail transport, Schengen area, customs code

\section{Introduction}

The development and cooperation of trading countries in international rail freight transport is greatly influenced by the way in which the wagon consignment is transported to the customer as quickly and smoothly as possible [1-3]. This is easier within the European Union, as most European Union countries have signed the Schengen Agreement [4]. It provides for various concessions necessary within the Schengen area. On the contrary, transport from west to east or east to west has to tackle various obstacles, e.g. change of transport procedure, change of gauge, customs controls, 
transshipment of goods, and others. Due to these technological constraints, it is important to set up the correct wagon consignments processing technology at rail border crossings [4-7].

\section{Customs Processing of Consignments}

The location of the Slovak Republic is significant not only because it is situated in the middle of Europe, but also because it is a point of the change of the transport regime in the international rail transport. The most important Eastern Slovak border crossing points include Čierna nad Tisou and Mat'ovce. In the transport from east to west and west to east, these are points where the change in transport regime occurs, as well as the change in track gauge. Another important fact affecting the passage of wagon consignments between the Slovak Republic and Ukraine is the need to cross the Schengen border. Customs controls are carried out on the territory of countries that are not members of the EU on the basis of the customs legislation of the Slovak Republic and EU legislation. The procedures and rules for the treatment of goods between third countries and the EU in the territory of the Slovak Republic are governed by the Customs Act. The Customs Act also governs measures to prevent illegal conduct of people in transit, import, and export [4-5,8-10].

The performance of customs tasks arising from the customs legislation of the EU and the Slovak Republic is ensured by ZSSK CARGO a.s. ZSSK CARGO a.s is subject to the internal legislation of the "KN 20". Each consignment crossing the Schengen border shall be recorded and subjected to physical checks by the competent customs office [11].

\subsection{Imports of Wagon Consignments across the EU External Border}

Prior to the entry of the consignment into the customs territory through the external border of the European Union, the carrier is obliged to submit an entry summary declaration in the electronic form to the customs office of entry before entering the territory of the Slovak Republic. This is done through the Information System to support the operation of ZSSK CARGO a.s.. The consignment must be presented to the customs office of entry together with all documents related to the goods transported. Upon the arrival of the train at the border crossing station, an authorised employee shall submit a transit document to the border crossing station. A transport inspection of the train must be carried out before the actual transfer $[9,11]$.

Customs control of the train on arrival shall be carried out by the Customs Office staff. When the customs representative proposes and presents all the documents necessary for initiating the procedure, the goods may be placed under the customs procedure as soon as the customs control has been completed [9-10,12-13]. 


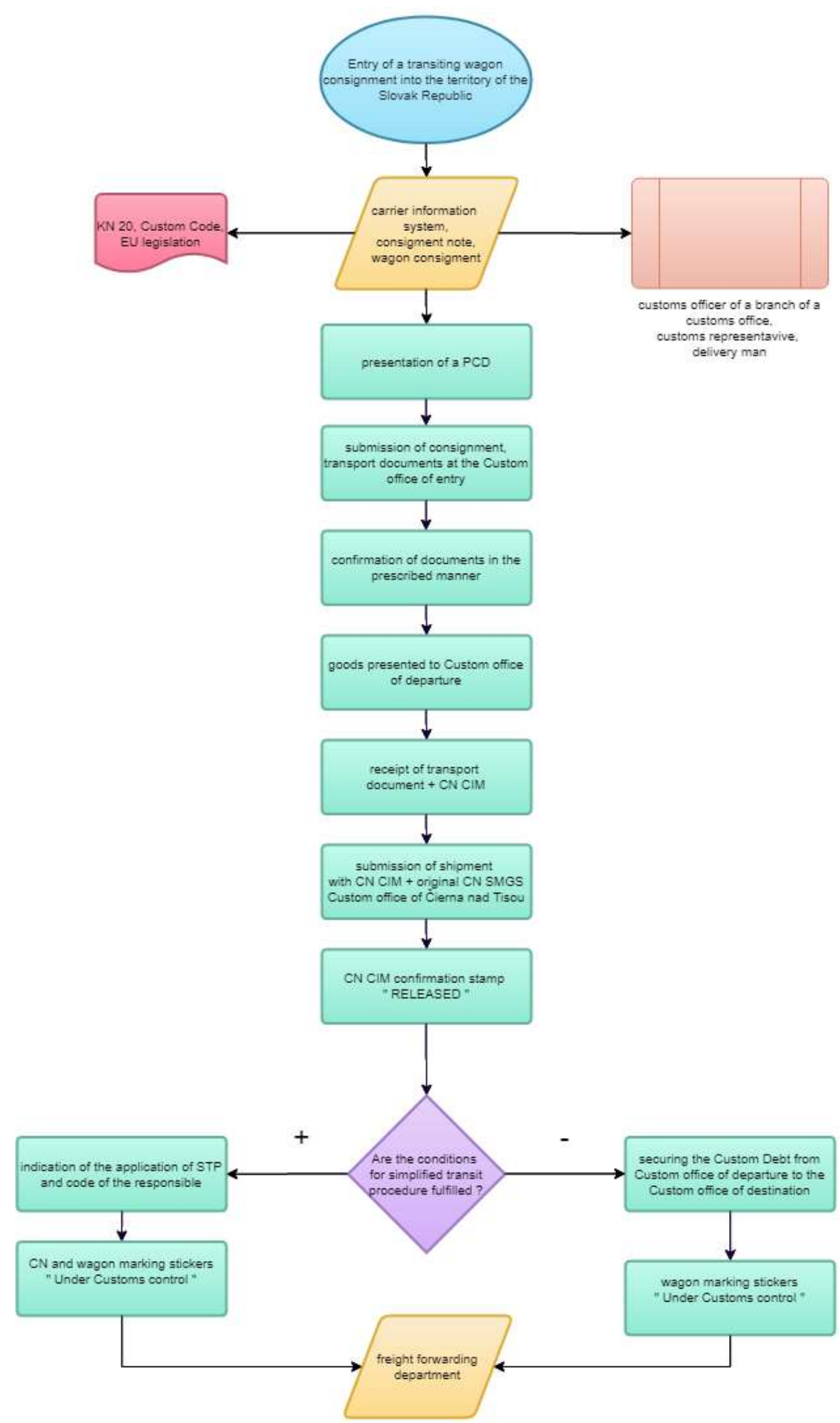

Fig. 1 Scheme of entry of transported consignment in process of customs clearance. Source: Authors (according to [11])

If goods are placed under customs control for customs clearance to the station of destination outside the territory of the Slovak Republic and the consignment enters the CN SMGS, the authorized employee of the border crossing station shall present the consignment to the customs office of entry together with the CN SMGS. The customs office of entry shall endorse the consignment note and the 
goods has the temporary status of stored goods. The main responsibility is borne by ZSSK CARGO a.s., which obliges the carrier to place the goods under a customs procedure. The goods shall be placed under the customs procedure of the $\mathrm{CO}$ of departure together with the CN CIM by which they were accepted for carriage. CN SMGS is also associated with this CN CIM, which serves as proof of prior transport [8-11]. The graphicpical representation of customs documentation processing is shown in Figure 1.

If goods are placed under customs control for customs clearance at the station of arrival within the territory of the Slovak Republic and the consignment enters the CN SMGS, an authorized employee shall present the consignment together with CN SMGS to the customs office of entry and endorse it. At the same time, the NCTS issues an electronic transit document to the CN SMGS [4,11]. The entire customs processing of the consignment is shown in Figure 2.

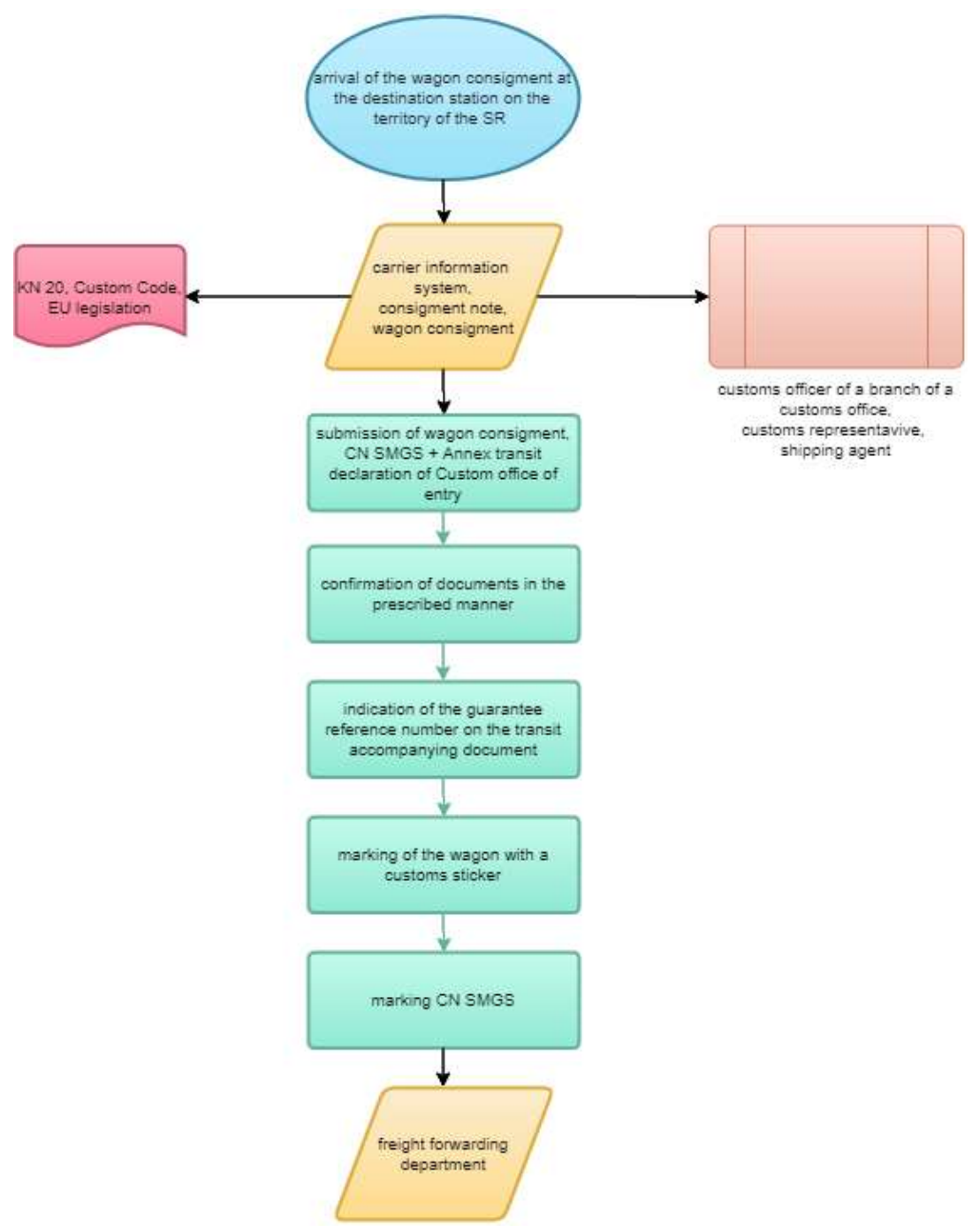

Fig. 2 Scheme of entry of consignment into the station of destination in the territory of the Slovak Republic. Source: Authors (according to [11])

Consignments that have not been placed under the proposed process in border crossing stations shall be tagged/labelled by the Customs Office of destination (inland). The Customs Office of entry 
thus becomes the Customs Office of dispatch. Such consignments must be preferably placed on board of the train and dispatched from the station of departure considering the time necessary for the delivery period to the Customs Office of destination. When the goods are intended for import, the Customs Office of dispatch shall carry out only an external check. Shall there be doubts that the data do not correspond to the facts, the Customs Office is entitled to carry out an internal check. $[9,11]$

\subsection{Transshipment of Wagon Consignments in Border Crossing Station}

The submission of the declaration for the release of goods - transhipped wagon consignments placed under the relevant customs procedure by the branch of Customs Office Čierna nad Tisou is provided by two customs representatives of the East Slovak transshipment points. The customs representative of the East Slovak transshipment points (transshipment) receives one copy of the transit document from the customs representative of the East Slovak transshipment points (SR). The transit document is delivered by the branch of Customs Office ČNT-transshipment. Upon the receipt of the consignment note for handling from an employee of the East Slovak transshipment points, the customs representative of the East Slovak transshipment points (transshipment) shall submit it to the branch of Customs Office ČNT - transshipment in order to request the approval of the branch of Customs Office ČNT for the attachment and transhipment of wagons specified in the command letter. The original copy of the letter of order with the written statement of the customs officer, stamped by the Customs Office, shall be delivered by the East Slovak transshipment points customs representative (transshipment) to an employee of the East Slovak transshipment points for archiving. If a customs representative of the East Slovak transshipment points (transshipment) receives the documents of transit wagon consignments from the forwarding department transport, specifically $\mathrm{CN}$ CIM with the original CN SMGS including all accompanying documents, it shall be ensured in accordance with the regulation KN 20 that each carrier involved in the transportation of goods within the EU or in the Common Transit Procedure meets the conditions for a simplified transit procedure [7-11].

If each carrier involved in the transportation meets the conditions for a simplified transit procedure, the principal code shall be entered and all parts of the CN CIM as well as the wagon rosters shall be labelled "Under customs control". If any of the carriers involved in the transportation does not meet the conditions of a simplified transit procedure, no entries in $\mathrm{CN}$ shall be made $[11,13]$.

It should be checked whether the transit document has been drawn up for the consignment and that it is annexed to the CN CIM. Subsequently, the customs representative of the East Slovak transhipment points (transshipment) shall submit CN CIM together with the original CN SMGS and all accompanying documents to the branch of Custom office ČNT - transshipment for customs clearance of the consignment. 
In the case of consignments to be released for free circulation together with the transport documents, the "Transshipment (control) sheet shall also be delivered. After receiving the transport documents from the branch of Custom office $\check{C} N T$ - transshipment, the customs representative of the East Slovak transshipment points (transshipment) checks CN to verify whether it contains all the particulars. After these operations, the customs representative of the East Slovak transshipment points (transshipment) delivers the transport documents to the commercial forwarding agent at the forwarding department, where the transport documents are processed. The entire course of customs processing of documents on transshipment is shown in Figure 3.

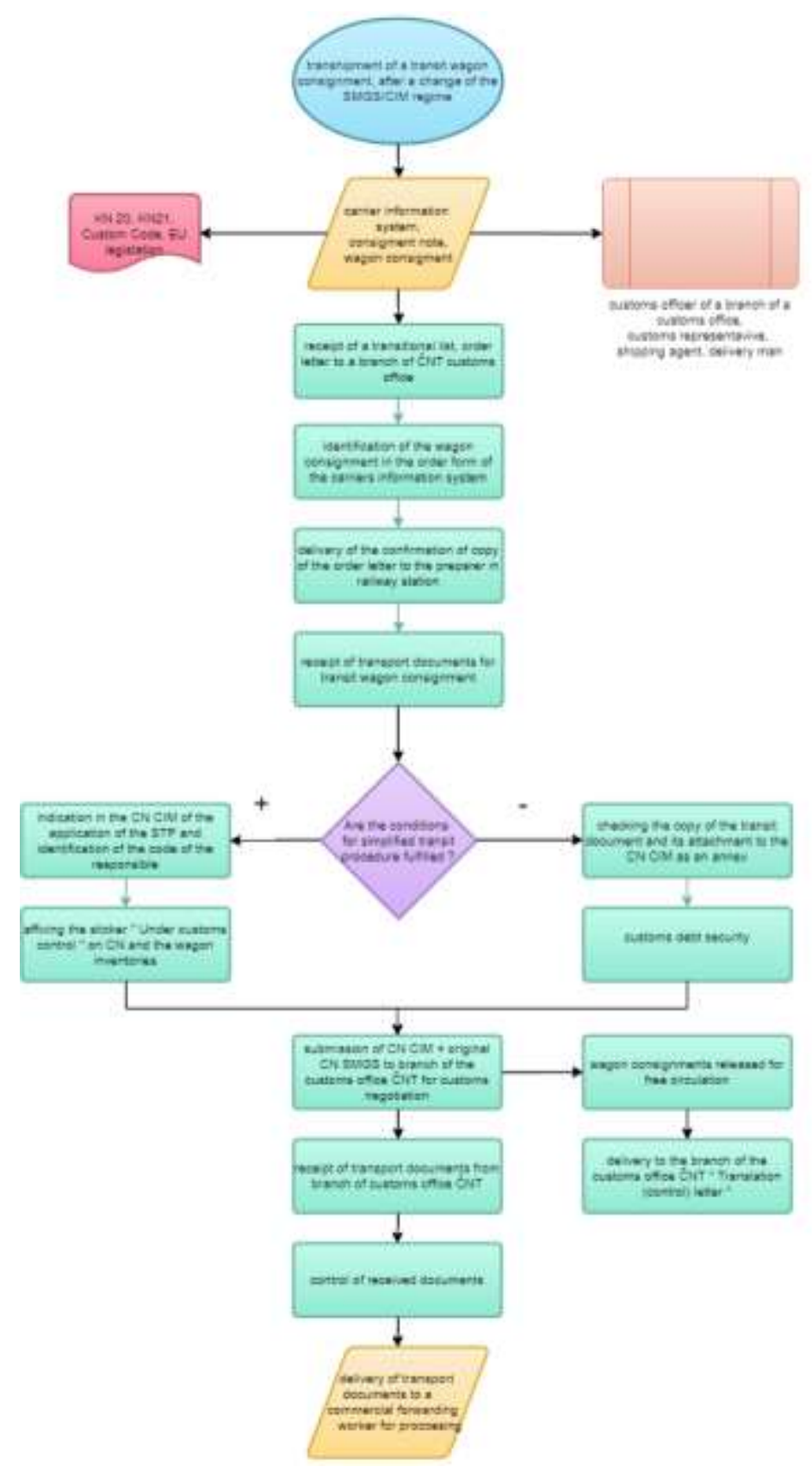

Fig. 3 Scheme of transshipment of wagon consignments following SMGS/CIM regime change.

Source: authors (according to [11]) 


\subsection{Exports of Wagon Consignments across the European Union's External Border}

Goods intended for export outside the EU and placed under the customs procedure shall be transported from the east to the exit border crossing station at the EU's external border under customs supervision. The consignment must be subject to clearance prior to its acceptance for transport. Clearance shall be provided by the consignor and shall be carried out at the Customs Office of departure locally competent for the station where the consignment is to be placed. When the consignment to be exported is lodged, the consignor shall produce an export accompanying document and attach all accompanying documents required for customs legislation. An employee of the station shall check the number of documents submitted and attached [8-10,14-15].

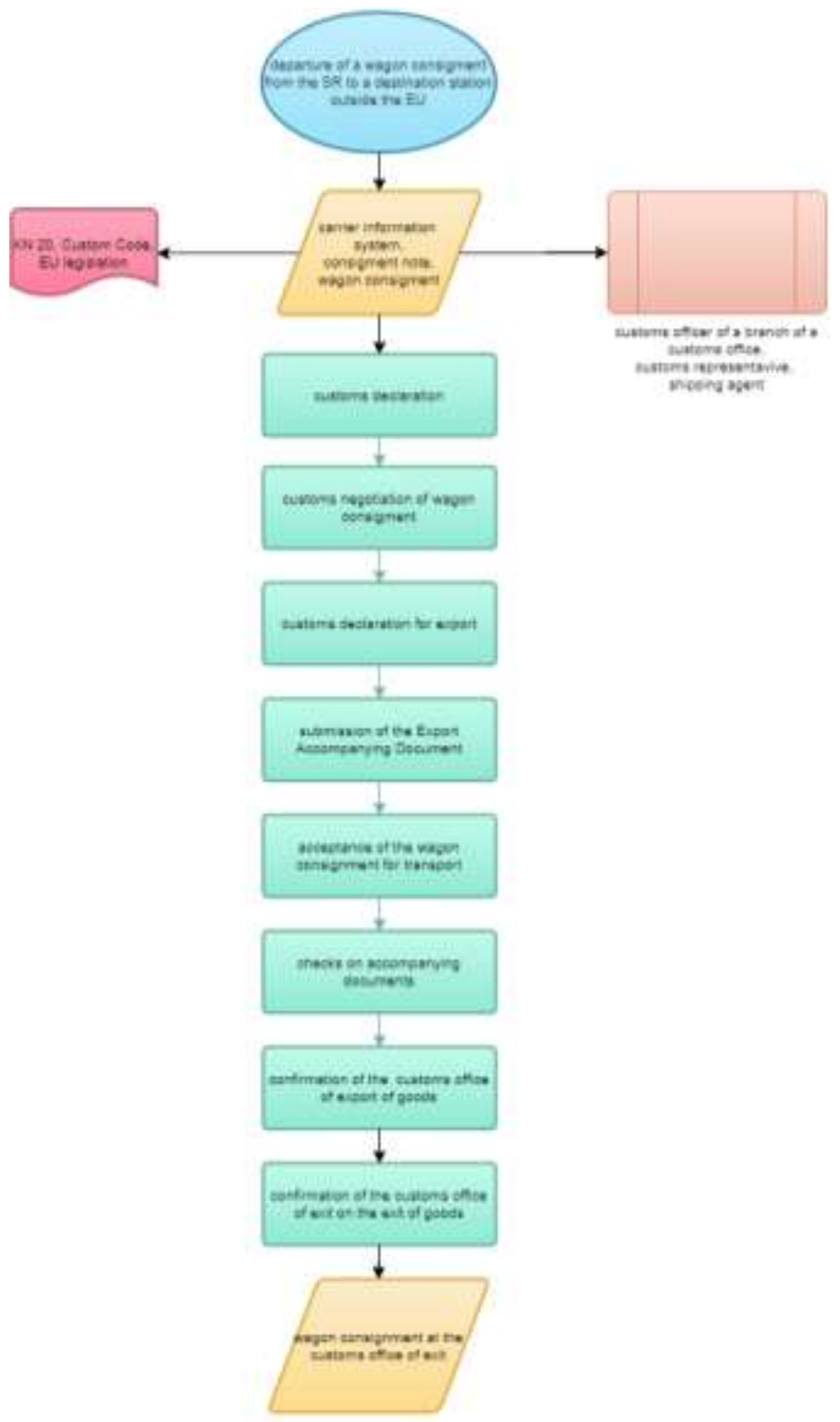

Fig. 4 Scheme of the process of exit of the consignment from the Slovak Republic. Source: Authors (according to [11]) 


\section{Conclusion}

The analysis of the customs processing of wagon consignments at the crossing of the SlovakiaUkraine border includes procedural maps by type of train at the border crossing station. There were created schemes of the entry of wagon consignments in transit, exit of wagon consignment, the entry of the consignment in the process of customs clearance at the station of destination within the territory of the Slovak Republic, and the transshipment of the consignment in transit after the change of SMGS/CIM mode.

All necessary train documentation and documents related to the transportation of the consignment are mostly submitted in paper form. Two hours before the arrival of the train at the border crossing station, a Summary Declaration and a transit document must be produced and submitted at the station upon arrival of the train. Subsequently, a representative of a transport office of East Slovak transshipments carries out technical and transport operations. Customs operations shall not be carried out until the customs authorities have been provided with the transport documents checked.

Electronic data exchange (EDE) is not a new idea, as it has existed on the market for decades. It represents a way of communicating between two independent entities. The exchange of structured, commercial documents and other documentation takes place electronically. Replacing paper documents with electronic documents is one of the main objectives of the EDE, as it also means a reduction in the costs associated with this exchange and at the same time streamlining the quality of the processes carried out. Paper documents do not lose their legal value when being converted into EDE documents. This system can interconnect several different information systems operating inside and outside the company.

One of the many solutions for streamlining the transportation of a consignment across the Schengen border is offered by EDE. The solution itself is to computerise all documents related to the transportation of consignments using EDE. With the current increasing demands for accelerating rail transport, this is a major step.

\section{Acknowledgments}

The paper is supported by the VEGA Agency by the Project 1/0791/18"The Assessment of Economic and Technological Aspects in the Provision of Competitive Public Transport Services in Integrated Transport Systems" that is solved at Faculty of Operation and Economics of Transport and Communications, University of Žilina. 


\section{References}

[1] Buková, B., Brumerčíková, E. \& Kolářová, P. (2015). A study of a logistics. Nase More 62(4), 256-263. DOI: 10.17818/NM/2015/4.3.

[2] Siroky, J., Schroder, S. \& Gasparik, J. (2017). Comparison of Operational and Economic Aspects of Direct Road Transport and Continental Combined Transport. Communications Scientific Letters of the University of Zilina, 19(2), 109-115. Retrieved October, 2, 2020 from http://komunikacie.uniza.sk/index.php/communications/article/view/193

[3] Gašparík, J., Abramović, B. \& Halás, M. (2015). New graphical approach to railway infrastructure capacity analysis. [Nový grafický prístup k zistovaniu kapacity železničnej infraštruktúry] Promet - Traffic - Traffico, 27(4), 283-290. DOI: 10.7307/ptt.v27i4.1701.

[4] Abramović, B., Zitricky, V. \& Biškup, V. (2016). Organisation of railway freight transport: Case study CIM/SMGS between slovakia and ukraine. European Transport Research Review, 8(4). DOI: 10.1007/s12544-016-0215-7.

[5] Ližbetin, J. \& Stopka, O. (2020). Application of specific mathematical methods in the context of revitalization of defunct intermodal transport terminal: A case study. Sustainability (Switzerland), 12(6). DOI: 10.3390/su12062295.

[6] Sañudo, R., Echaniz, E., Alonso, B. \& Cordera, R. (2019). Addressing the Importance of Service Attributes in Railways. Sustainability 11(12), 3411. DOI: 10.3390/su11123411.

[7] DG Move outlines key priorities for EU railways (2020). RailTech.com. (n.d.). Retrieved October 8, 2020, from https://www.railtech.com/policy/2020/02/24/dg-move-outlines-keypriorities-for-eu-railways/?gdpr=accept.

[8] Konečný, V., Semanová, Š., Gnap, J. \& Stopka, O. (2018). Taxes and charges in road freight transport - A comparative study of the level of taxes and charges in the slovak republic and the selected EU countries. Nase More, 65, 208-212. DOI: 10.17818/NM/2018/4SI.8.

[9] Regulation (EU) No. 952/2013 of the European Parliament and of the Council of 9 October 2013 laying down the Union Customs Code. Retrieved October 9, 2020, from https://eurlex.europa.eu/eli/reg/2013/952/oj.

[10] Pečený, L., Meško, P., Kampf, R. \& Gašparík, J. (2020). Optimisation in transport and logistic processes. Paper presented at the Transportation Research Procedia 44, 15-22. DOI:10.1016/j.trpro.2020.02.003.

[11] ZSSK Cargo (2020). Custom services - KN 20, work schedule of ZSSK CARGO 2020. Retrieved July 22, 2020 from https://eur-lex.europa.eu/eli/reg/2013/952/oj.

[12] Černá, L., Lupták, V., Šulko, P. \& Blaho, P. (2018). Capacity of main railway lines - analysis of methodologies for its calculation. Nase More 65(4 Special issue), 213-7. DOI 10.17818/NM/2018/4SI.9.

[13] Shift2Rail. (2019). Shift2Rail Joint Undertaking Multi-Annual Action Plan Part B Draft 2019 05 20. Brussels.

[14] Dedík, M., Gašparík, J., Záhumenská, Z., L’upták, V. \& Hřebíček, Z. (2018). Proposal of the measures to increase the competitiveness of rail freight transport in the EU. Nase More 2018;65(4 Special issue):202-7. DOI: 10.17818/NM/2018/4SI.7.

[15] Lukáš, L. (2011). Information support of the integrated rescue system (in Czech), ISBN 97880-7385-105-7, Association of Fire and Safety Engineering. 